\title{
OPEN
}

Published online: 13 February 2020

\section{Publisher Correction: Palm Fruit Bioactives augment expression of Tyrosine Hydroxylase in the Nile Grass Rat basal ganglia and alter the colonic microbiome}

\section{Robert P. Weinberg, Vera V. Koledova, Avinaash Subramaniam, Kirsten Schneider, Anastasia Artamonova (D), Ravigadevi Sambanthamurthi, K. C. Hayes, Anthony J. Sinskey \& ChoKyun Rha}

Correction to: Scientific Reports https://doi.org/10.1038/s41598-019-54461-y, published online 09 December 2019

The Article contains an error in Table 3, entitled "Semi-quantitative comparisons of CNS proteins by IHC staining."

In the "Tyrosine Hydroxylase" row under the "DM-resistant, with PFB" column, the value of 7+ was erroneously omitted.

(c) (i) Open Access This article is licensed under a Creative Commons Attribution 4.0 International License, which permits use, sharing, adaptation, distribution and reproduction in any medium or format, as long as you give appropriate credit to the original author(s) and the source, provide a link to the Creative Commons license, and indicate if changes were made. The images or other third party material in this article are included in the article's Creative Commons license, unless indicated otherwise in a credit line to the material. If material is not included in the article's Creative Commons license and your intended use is not permitted by statutory regulation or exceeds the permitted use, you will need to obtain permission directly from the copyright holder. To view a copy of this license, visit http://creativecommons.org/licenses/by/4.0/.

(C) The Author(s) 2020 